\title{
Automobile Sales in Perspective
}

\author{
JAMES E. TURLEY
}

\begin{abstract}
D. UE to both its relative size and its tendency toward large cyclical fluctuations, the automobile industry has tended to receive a great deal of attention in analyses of current economic conditions. In terms of new car sales, developments of the past three years have been particularly well publicized, popular topics of concern. In part, this has probably been a response to the impact of the oil embargo which highlighted developments in a number of industries. The purpose of this article is to provide some perspective on this recent period by comparing it with the pattern of new car sales in the previous three recession/recovery periods.
\end{abstract}

\section{ECONOMIC IMPACT OF AUTOMOBILES}

In 1972 (latest data available) expenditures for passenger and freight transportation totaled $\$ 208.7$ billion, or 18 percent of GNP in that year; passenger transportation expenditures related to automobiles accounted for over half of this amount $-\$ 111.6$ billion. ${ }^{1}$ About 26 percent of all retail sales and 19 percent of all wholesale sales were automotive related in that year. Employment in motor vehicle and equipment manufacturing totaled 858,100 in 1974 , or 4.3 percent of total manufacturing employment.

In addition, the health of the automobile industry has a profound impact on a number of so-called "feeder" and related industries. The rubber industry, in particular, is extremely sensitive to changes in the economic condition of the automobile industry. For example, 74 percent of the rubber consumed in the United States in 1973 was related to consumption of automobile services. Consumption of lead for auto-

\footnotetext{
Included in the auto transportation figure are expenditures for new and lised cars, gasoline and oil, insurance, auto registration fees, and repairs. For additional infomation, see Motor Vehicle Manufactenrers Association, 1975 Attomobile Facts and Figures, p. 53.
}

motive usage amounted to 63 percent of total U.S. consumption in 1973. Iron, zinc, and steel are the next most dependent industries with 47,33 , and 21 percent, respectively, of their consumption accounted for by antomobiles. Financial institutions are also affected by the automobile industry. As an example, installment credit extended for automobile purchases amounted to one-third of total consumer installment credit raised in 1975 .

The revenue generated from automotive-related purchases represents an important source of funds for government operations. For example, in 1974 the Federal Government collected $\$ 6.1$ billion in excise taxes on such purchases as motor fuel, tires, trucks, buses, and trailers. State revenues from motor use taxes amounted to 16 percent of total funds collected by the states in fiscal $1974 .^{2}$

\section{HISTORICAL OVERVIEW OF AUTO SALES}

Growth of the automobile industry has been subm stantial in the past 26 years, with auto sales slightly outpacing the growth of the economy in general. Total new car sales, including imports, have increased at a 4.7 percent annual rate, rising from about 3.5 million units in 1948 to a peak of 11.4 million in 1973. For comparison, production of all goods in the nation advanced at a 4.3 percent rate over this period.

\section{Trend Growth}

As indicated in the accompanying chart, the rise in new auto sales has not been steady or uniform. There have been boom periods followed by periods of sluggishness, but the trend has been unmistakably

\footnotetext{
New Hampshire collected the highest proportion of funds from this source, with 34 percent of its revenue originating from motor use taxes.
} 


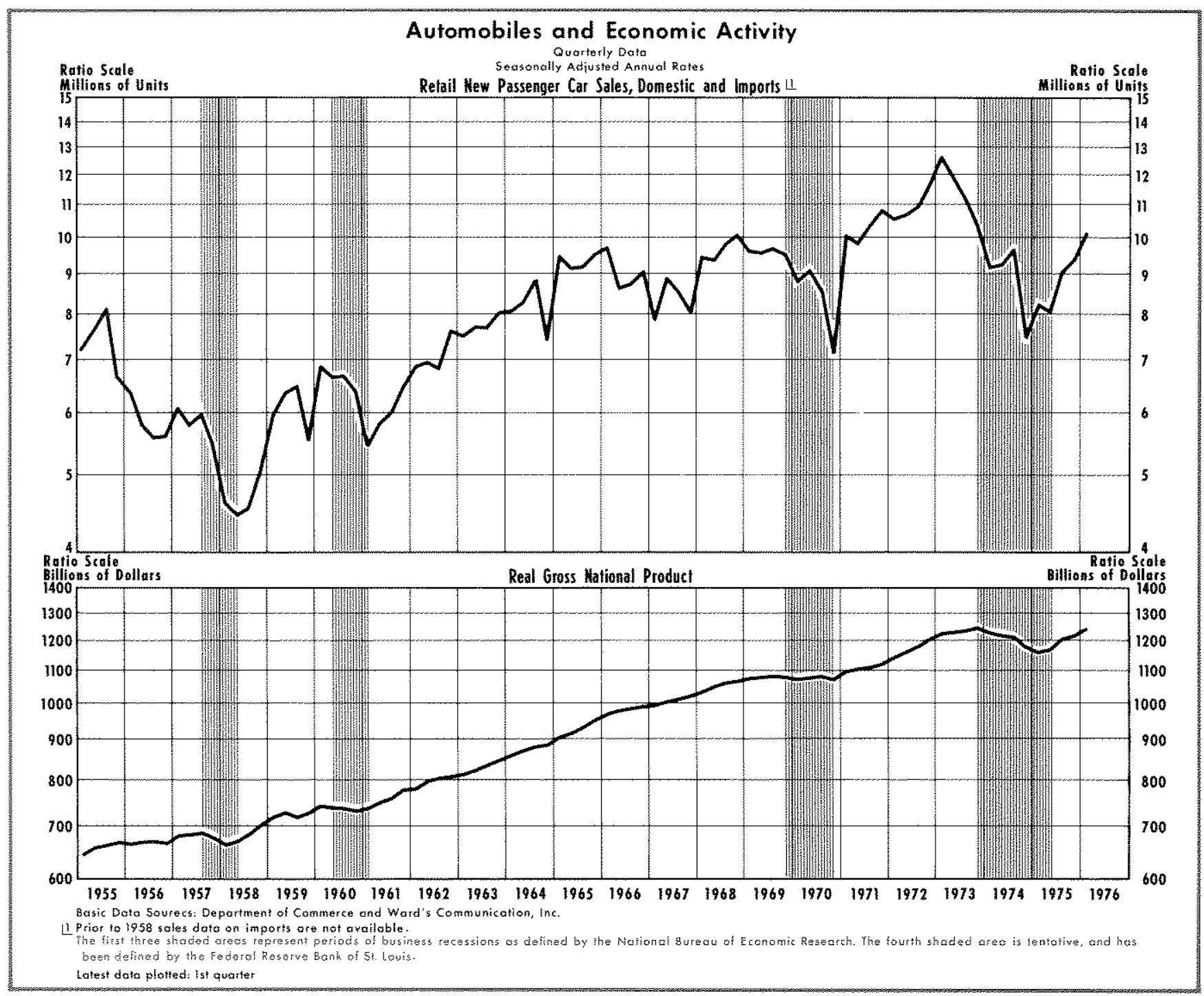

upward. In general, each periodic crest and trough has occurred at a higher level than the previous high and low points. For example, the year 1955 was a banner year with new car sales of 7.4 million units; three years later sales fell to 4.7 million units. In 1965, auto sales were recorded at a high of 9.3 million units; two years later, in 1967 , sales had fallen to a relative low of 8.3 million units.

The upward trend in auto sales is related to several factors, one of which is the trend growth of disposable personal income adjusted for the effects of inflation. Such a measure is generally regarded as an indication of an individual's ability to purchase goods and services. Since 1955 this measure of purchasing power has increased at a 3.4 percent annual rate.

Another important factor in the determination of the trend growth in auto sales is the price of autos relative to the prices of other goods and services. As can be seen in the accompanying chart, since early 1959 the price of new automobiles has declined relative to all goods and services - that is, there has been a shift of relative prices in favor of new automobiles. Even considering the substantial price boosts posted by the auto manufacturers recently, the new car price index relative to the consumer price index (CPI) is 35 percent below its peak of early 1959.

In this regard, it is interesting to note the behavior of new car prices relative to other prices during recessions. The overall downward trend is halted during economic contractions as the relative price of new cars either rises or, on balance, remains essentially unchanged. Available data indicate that this pattern tends to be the result of overall prices slowing and auto prices accelerating during recession periods. In other words, prices of other goods appear to be more 


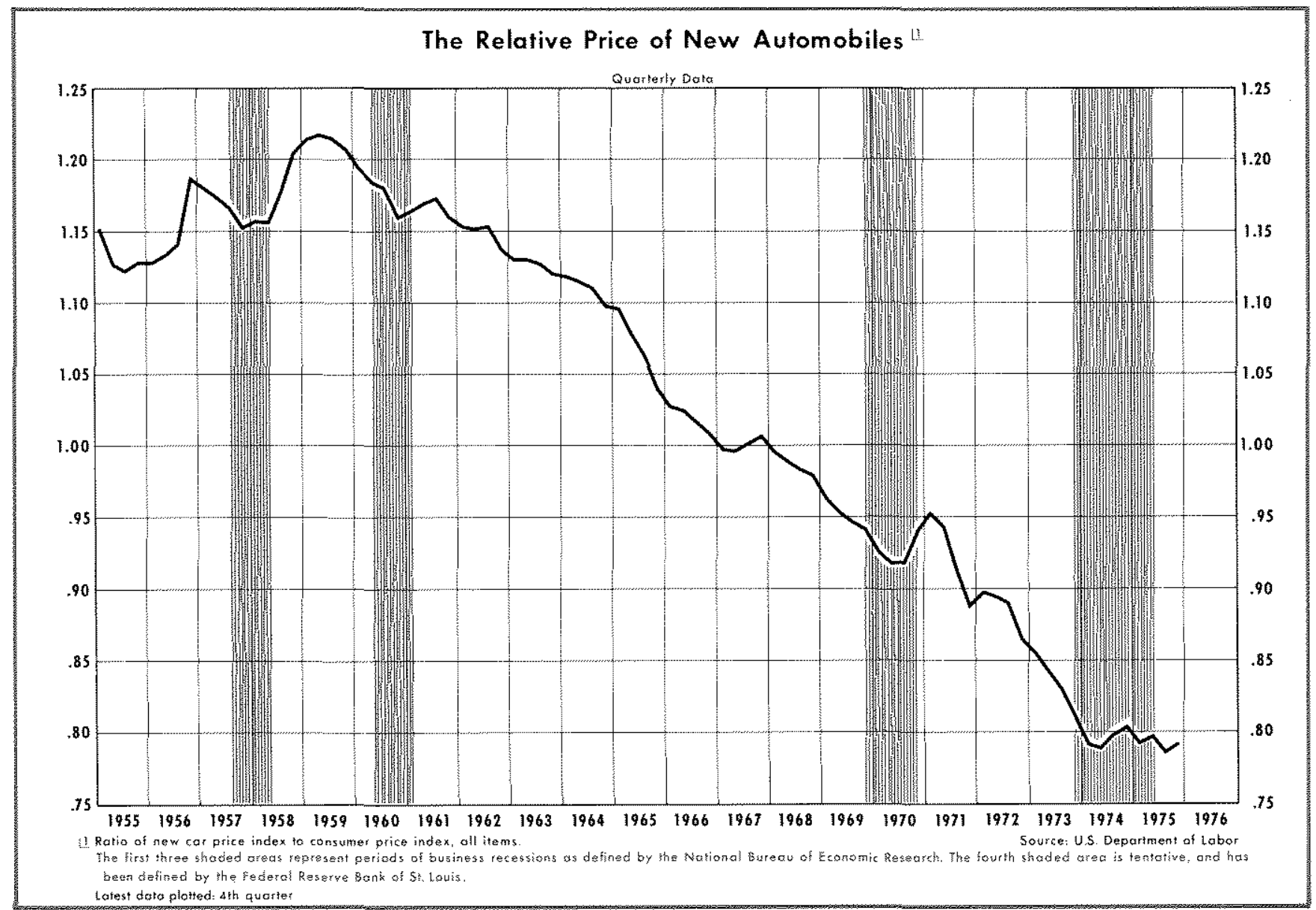

responsive to the deflationary forces of recession than do new automobile prices. ${ }^{3}$ For example, the upturn in the relative price of autos from second quarter 1970 to first quarter 1971 was the result of new automobile prices posting a 9.9 percent rate of gain and the CPI increasing at a 4.5 percent rate. In the four previous quarters, new automobile prices and the CPI increased at respective rates of 2 and 6 percent.

The upward trend in retail sales of new cars is also related to demographic developments which have affected the demand for autos. For example, the number of individuals with licenses has increased in both level and as a percent of the population of driving age. In 1955, 75 million individuals were

3 This relative downward inflexibility of anto prices in recessions, coupled with the observation made by others that the demand for automobiles is relatively more responsive to changes in income implies, a greater adjustment downward in the number of units sold than would be the case if auto prices were more responsive to deffationary forces. For a summary of various estimates of income elasticity, see "The Demand for Automobiles," Senate Subcommittee on Antitrust and Monopoly, in Donald Stevenson Watson, Price Theory in Action (Boston: Houghton Miflin Company, 1965), p. 23. licensed, which represented about 66 percent of the population 16 years of age and older; in 1974, there were about 125 million licensed drivers, or 83 percent of the drivingwage population. In the mid-1950s, only 10 percent of all families in the nation owned two or more cars; in 1971, about 30 percent of all families owned two or more automobiles.

\section{Market Shares}

The composition of new automobile sales between foreign and domestic models has undergone significant change since 1947. In general, auto imports have represented an expanding proportion of the total new car market, although there are current indications that this trend is being reversed or at least being halted temporarily. Up until about 1955, the percentage of new car sales attributable to imports was negligible, less than one percent. Over the next four years imports increased to 10 percent of the new car market, then by 1962 slipped to under 5 percent. From 1962 through 1974 , the upward path was reestablished, with 16 percent of 1974 new car sales attributed to imports. 
Beginning in 1975, however, another reversal appears to be taking shape. With the narrowing in the price differential between foreign and domestic models, among other factors, sales of imports have recently become a declining portion of new auto sales. In first quarter 1975, imports were credited with about 20 percent of total new car sales; in first quarter 1976, this proportion had fallen to about 13 percent.

\section{CYCLICAL CONSIDERATIONS}

The trend growth of auto sales has been far from smooth or steady. In fact, automobile sales, like most durable goods, have been highly volatile in the short run. Among other factors, such volatility appears to be closely related to an individual's perception of near-term income and employment prospects. ${ }^{4}$

Expectations about future economic conditions are very influential forces in the decision to purchase a durable good, such as a new auto. Prior to and during periods of business contractions, expectations about the future become increasingly clouded. As unemployment rises, uncertainty about future income increases and individuals reduce purchases of "bigticket" items, such as many durable goods. These purchases can be delayed until individuals again expect more favorable economic conditions to prevail. Autos appear to be quite sensitive to such changes in expenditure decisions.

\section{Timing}

The downturn in automobile sales has generally tended to lead the downturn in aggregate activity, although the lead time in the past four recessions has been variable. In the 1973-75 recession, auto sales peaked about three quarters prior to the generally recognized peak in overall economic activity, Autos posted a record annual sales rate of 12.6 million units in first quarter 1973, while the peak in aggregate activity was not reached until fourth quarter 1973 . In the recessions of $1969-70,1960-61$, and 1957-58, the downturns in auto sales preceded the contractions in economic activity by four, one, and two quarters, respectively.

During economic expansions, auto sales generally begin picking up about the same time as aggregate activity. In the 1970, 1961, and 1958 periods of aggregate expansion, the upswing in auto sales co-

\footnotetext{
4For a more thorough discussion of the role of expectations in the determination of short-run movements in auto sales, see Ron P. Smith, Consumer Demand for Cars in the U.S.A.
} (London: Cambridge University Press, 1975).

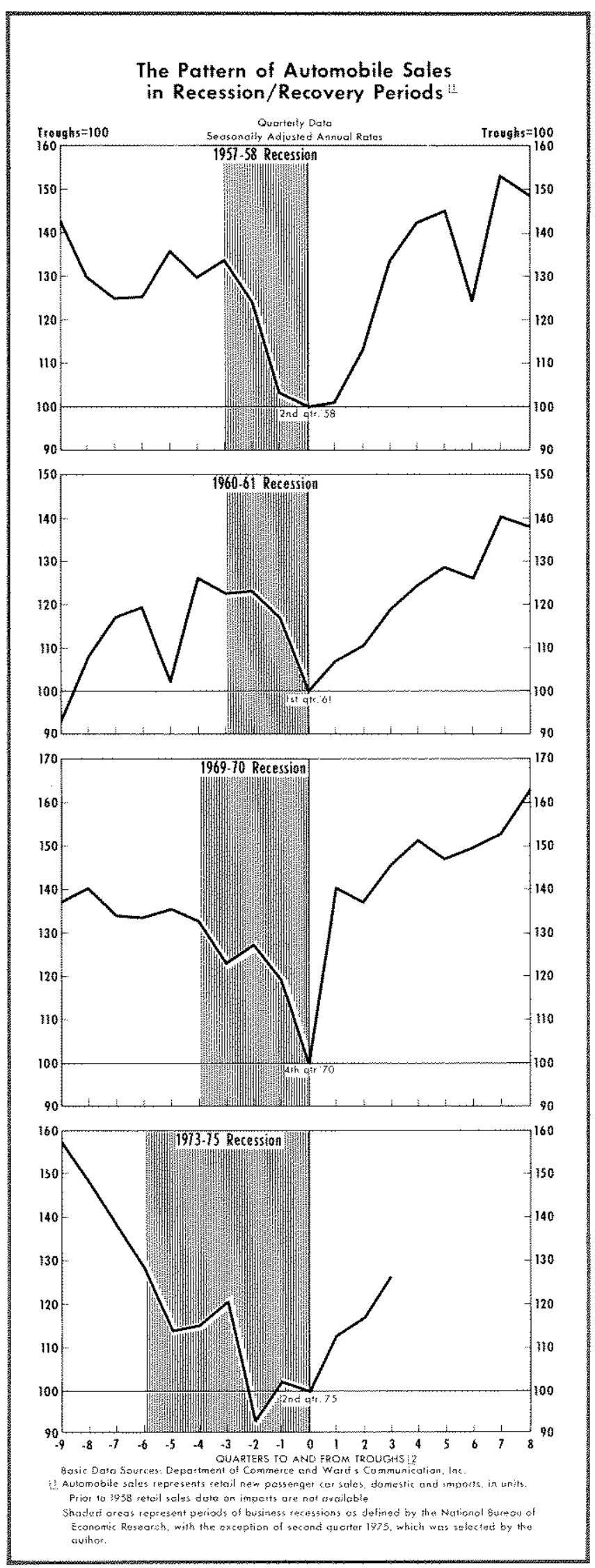


incided with the upswing in overall activity. In 1975, however, it appears as if auto sales picked up about two quarters prior to the economy in general. ${ }^{5}$ Boosted by the offer of rebates on new car purchases, auto sales increased in first quarter 1975 from its trough in fourth quarter 1974.

\section{Magnitude}

Recession - Any downward movement in overall economic activity, as measured by real GNP, tends to be magnified several times over for automobiles. For example, as shown in Table I, real GNP in the past four recessions has declined in a range of between 1.1 percent in the $1969-70$ period and 6.6 percent in the $1973-75$ period. Purchases of new automobiles, however, have posted declines ranging from 20.7 percent in $1960-61$ to 40.7 percent in $1973-75 .^{\circ}$

As can be seen by these numbers, the more severe the downtum in aggregate activity, the sharper is the drop in auto sales. But this relationship between autos and overall economic performance is far from systematic. For instance, the 3.2 percent decline in real GNP in 1957-58 was associated with a near 32 percent decline in new car sales. Although the decline in real GNP in 1973-75 (6.6 percent) was twice as great as in $1957-58$, the decline in auto sales was only somewhat greater ( 40.7 percent).

Recovery - With respect to economic upswings, the same pattern of pronounced changes in auto sales relative to real GNP seems to hold; but again, there does not appear to be a tight relationship between the strengths of the expansions displayed by the two series.

For example, in the four quarters following the troughs in real GNP in 1975 and 1958, this measure of real activity advanced by 7.1 percent; however, the expansion in total auto sales in the earlier period was much stronger than that displayed for the current period -42.4 percent versus 25.3 percent. The sharpest rebound in auto sales was posted in the year following the relatively mild recession of $1969-70$; real GNP expanded 4.6 percent while new auto sales

\footnotetext{
5Timing aspects in the 1975 recovery period are somewhat more difficult to detemine. The judgenent of the National Bureau of Economic Research (NBER) is generally accopted for the purpose of determining the turning points in agrregate activity. This determination has not yet been made for the most recent trough, although the NBER is using April 1975 as a preliminary estimate. The second cuarter of 1975 is used here as the terminal quarter of the latest recession.

whe actual peaks and troughs in real GNP and auto sales are not necessarily the same as those defined by the NBER
} for the aggregate economy. See footnotes to Table I.



increased by about 51 percent. ${ }^{7}$ In the four quarters of expansion following its trough in the 1960-61 recession, real GNP increased about 6 percent and automobile sales rose 26 percent.

In the early recovery periods of the last three recessions, essentially all of the increase in auto sales has been accounted for by domestic models. A negligible ( 0.3 percent) rise in sales of foreign autos in the period of recovery from first quarter 1975 to first quarter 1976 compares with actual declines $(-4.6$ and -7.3 percent, respectively) in the four

TSome distortion is introduced into the GNP and auto sales data by the automobile strike in fourth quarter 1970 . 
quarters following the two previous business contractions. Sales of imports in the 1958-59 recovery period posted an exceptionally large gain in percentage terms, but this is primarily the result of the relatively small base associated with the level of imports in this period.

\section{CONCLUSTONS}

It was generally argued over the course of this most recent recession that the auto industry was especially hard hit because not only were the typical forces of recession placing downward pressure on auto sales, but a number of special factors were also serving as sales depressants. These special factors included substantial price boosts posted by the auto manufacturers, uncertainty about the availability and price of petroleum products generated by the oil embargo, and general consumer resistance to the Government-mandated pollution and safety equipment.

All of these factors were supposedly accentuating the plight of the auto industry in 1973-76 and when viewed in isolation, the numbers associated with the swings in auto sales appear to be substantial. But, when viewed in the context of previous recession/ recovery periods, the numbers are somewhat less surprising. In particular, when one considers the extent of the decline in overall economic activity in the recent recession and the subsequent expansion in the aggregate economy, movements in new auto sales in the 1973-76 period do not appear to be significantly out of line with the general pattern observed in the three previous recession/recovery periods.

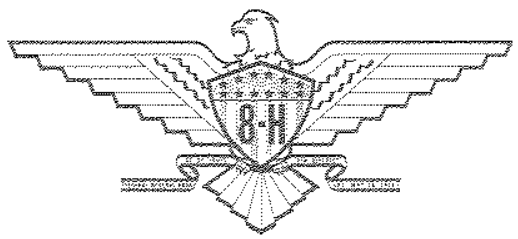

